\title{
KÉSŐI SZÜRETELÉSRE ALKALMAS SZŐLŐFAJTÁK CUKORTARTALMÁNAK ÉS ÖSSZETÉTELÉNEK ALAKULÁSA AZ ÉRÉS SORÁN
}

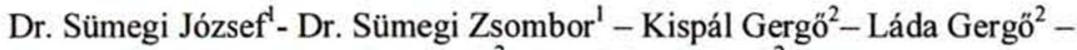 \\ Dr- Véha Antal ${ }^{2}$ - Dr. Gyimes Ernö ${ }^{2}$ * \\ 'Keller Kft Baja, \\ ${ }^{2}$ SZTE Mẻrnőki Kar Élelmiszermérnőki Intézet * levelezö szerző
}

\section{SUMMARY}

In the last few years more and more people can discover the taste of dessert wine which need special so called "late harvested" grape. This paper present the changes of sugar content $(\mathrm{SC})$ as well the glucose $(\mathrm{G})$ and fructose $(\mathrm{F})$ ratio during ripening. Common case the $\mathrm{G}$ and $\mathrm{F}$ ratio is $1: 1$, in the over matured grape the fructose content is higher.

\section{BEVEZETÉS}

Napjainkra a fokozódó verseny és az egyre szigorúbb szabályozások olyan szakágazattá fejlesztették a szölészet és borászat területét, ahol magas szintü elméleti, technológiai és gyakorlati ismeretek nélkül nehéz az élmezőnyben maradni. A versenyben azok lehetnek eredményesek, akik a tradíciók mellett az innovációt is sikeresen alkalmazzák, legyen szó akár az alapanyagok módszeres vizsgálatáról vagy új termékek előállításáról.

A jégbor mellett izgalmas területnek igérkezik késöi szüretelésũ szölökböl származó borok készítése, amely különleges technológiai kihívás.

Kulcsszavak: szőlö, szüret, jégbor, szölő cukortartalma

\section{IRODALMI ÁTTEKINTÉS}

A szölő a magvas növények (Spermatophyta) közé tartozik. A zárvatermők tagozatán (Angiospermatoohíta) belül, a kétszikủek osztályába (Dicotyledonae), a rózsaalkatúak alosztályának (Rosidae), Celastranae felrendjébe tartozó, varjútövis virágúak (Rhamnales) rendjébe, a szőlőfélék (Vitaceae) családjába sorolják. A család 10 nemzettséget foglal magába, melyek két alcsaládot, a Muscandina-t, és az Euvitis-t alkotnak. Nagyjából 675 fajuk került leírásra, melyeknek számtalan, a folytonos nemesítő munka eredményeként napjainkban is gyarapodó fajtája ismeretes (ZANATHY, 1999).

A szölők életciklusát négy részre oszthatjuk. Az első rész, az ültetést követö időszak. Ekkor a növény gyökérzete rohamos növekedésnek indul, melynek hatására a tápanyagfelvétel is jelentős mértékben növekszik. Ez a ciklus 4-6 évig tarthat. A második részben, a termöre fordulással a generatív részek is fejlődésnek indulnak a növényi hormonok hatására. Kialakul az összetett virágzat, majd a termékenyítés hatására a termésképzés lép elötérbe. $\mathrm{A}$ fokozódó termőképesség időszaka. Nagyjából 5-10 évig tart. A növény, életének harmadik szakaszában a fajtájára jellemző maximális termésmennyiséget produkálja. Kiegyenlített terméshozam jellemzi az időszakot, mely 40-től akár több száz évig is eltarthat. Az utolsó életciklus az elöregedés. Gyengül a növekedés, a biológiai funkciók, valamint a terméshozam és a minőség is. Az ültetvény ilyenkor már nem nyereséges (ZANATHY, 1999, BÉNYEI et al. 1999).

A szőlő növény fénykedvelö, fényigényes növény. Az intenzív növekedés és magas hozam eléréséhez minél több napfényt kell biztosítani számára, ezért ültetik a hegyek, dombok déli lejtőire. Szórt fény mellett is növekszik, azonban ekkor a termésben található cukor-sav arány messze átlagon alul marad (EPERJESI I. - KÁLLAY 1998). Hőigénye fajtánként változik, azonban általánosan elmondható, hogy a téli, nyugalmi időszak végén a növény 
élettevékenységeinek elindulásához nélkülözhetetlenül szükséges $9-11{ }^{\circ} \mathrm{C}$. Egyes területeken ez az érték alacsonyabb is lehet. A növény hötürése nagyon jó, az igen magas hỏmérsékleteket is elviseli. Télen a hosszan tartó, $-15{ }^{\circ} \mathrm{C}$ alatti hideg azonban kárositja, rügyei, vesszöi elfagyhatnak (EPERJESI ET AL.,2010).

A szölö termése a szőlöfürt. Két jól elkülöníthető részre tagolható, a kocsányra és a szölöbogyókra. Elöbbi, mint váz, tartja a gyümölcsöket. A kocsány elfásodhat, a vesszőkhöz hasonló szint ölthet. A kocsány és a bogyók súlyaránya sok mindentöl függhet, az érettségi foktól, egészségi állapottól, valamint a szőlö fajtájától is. Ez a fürt össztömegének zsendüléskor $10-20 \%$, érett állapotában 3-7\%-át teszi ki. A kocsány összetételét tekintve hasonlit a levelekhez vagy a kacsokhoz. Cukortartalma igen szegény, viszont magas a kötött sav valamint ásványi anyag tartalma (BAKONYI ET AL. 2005). A szölö gyümölcs valódi bogyótermés. A bogyók színe, alakja, nagysága fajtára jellemzö, bár sok egyéb tényező is befolyásolja, például az éghajlat, talaj, vagy éppen a növény egészségi állapota. A szölöbogyókat többféle módon tudjuk csoportositani. A három fö szempont az alak, méret és szín szerinti különbségük. Formájukat tekintve igen változatosak lehetnek. Ha csak a termést vizsgáljuk, ez az egyik legszembetűnőbb és legállandóbb fajtajelleg. Gömbölyü, ovális vagy tojásdad bogyóalakok a leggyakoribbak, azonban számos további forma is kialakulhat. (KÁLLAY, 2010, BÉNYEI et al. 1999).

A szölő és minden egyéb növény esetében nagyon nehéz megállapitani, mikor éri el a teljes érettséget. Ez nem abszolút fogalom, mivel nincsen meghatározható biológiai határértéke. Az érés egy folyamat, melyet fokozatokra tudunk bontani, ám ezek közt sincs éles határ. A szölő fajtája, éghajlati tényezők, sőt még az agrotechnika is nagy mértékben befolyásolja. (EPERJESI-KÁLLAY, 1998)

Az érés pontos megállapitása, a szüret időpontjának helyes megadása miatt fontos. Két féle fokozatot különböztethetünk meg, a teljes, vagy biológiai, illetve a technológiai érettséget. A technológiai érettség alatt azt értjük, hogy a bogyóban felhalmozódott anyagok aránya és mennyisége már kielégitö számunkra, szüretelhetö a fajta. Vannak esetek, mikor a két fokozat időben nem különül el, de ez igen ritka. A lehető legjobb minöség a teljes érettség alatt érhető el, azonban általában a szölő hamarabb eléri a technológiai érettséget, tehát a szüretelhetőségi határt.

A szölöbogyó növekedése, valamint érése során többféle cukorféleséget tartalmazhat, melyek föként a bogyóhúsban koncentrálódnak. Ezek az anyagok a levelekben vagy a zöld, klorofil tartalmú bogyókban képződnek. A szénhidrátok jelentős hányadát, körülbelül $90 \%$-át redukáló cukorféleségek adják, melyek a glükóz és a fruktóz, de ezeken kivül tartalmaz még kis mennyiségben szacharózt, maltózt, galaktózt, raffiniózt, arabinózt, melibiózt és stachiózt (MÁRKUS, 2006). A szölőbogyó szénhidrátokon kívül, jelentős mértékben tartalmaz szerves savakat is. Ezek a savak föként borkösav és almasav, valamint kisebb arányban citromsav. Jelentéktelen mennyiségben találunk a bogyóban egyéb savakat is, de ezek együttesen alig teszik ki az összes savtartalom 2-3 \%-át. Három csoportot különböztetünk meg, a szabad, a félig kötött, valamint a kötött savakat. Az elsö két osztályba tartozó vegyületek adják a szőlőbogyó savanyú izét. A savtartalom alakulásának ismerete fontos kritérium ahhoz, hogy a megfelelö minöségủ és savasságú szőlő szüretidejét megállapíthassuk (KÁDÁR, 1982).

Késői szüretelésböl származó szölök esetében értelemszerüen a biológiai érettséget követöen, tehát nem azt megelözöen történik a szüretelés, ezért is fontos tisztában lenni az érettséggel összefüggésben tapasztalható folyamatokról, leginkább a cukortartalom alakulásával, nem megfeledkezve arról a tényröl, hogy a savtartalom alakulása legalább ilyen jelentős tényező. 


\section{ANYAG, ESZKÖZ, MÓDSZER}

Kétféle fehér szőlővel végeztünk vizsgálatokat, ezek az Olaszrizling és a Cserszegi füszeres fajták voltak.

Az Olaszrizling fajtát, neve után Olaszországból származtatnánk, azonban a XIX. században Franciaországból érkezett hazánkba. Az egyik legelterjedtebb fehérbort adó szőlöfajta. A szőlötermesztő országok közül, nálunk, Magyarországon fordul elő a legnagyobb termő területtel. Az 1874 utáni nagy filoxéra pusztítás után terjedt el igazán. Igen közkedvelt fajta, amely 1956-ban kapott állami elismerést. Hosszú tenyészidejü, későn érő fajta. Kis fürtje ellenére bőtermő, mely egyes adatok szerint 13-14 t/ha is lehet. A bogyó cukortartalma 15-17 $\mathrm{Mm}^{0}$ közt változhat, de jó évben elérheti a $20 \mathrm{Mm}^{0}$-ot is. Mindehhez átlagos, 8-9 g/l-es savtartalom társul. A Cserszegi füszeres fajtát Keszthely közelében, Cserszegtomajon nemesítette ki Bakonyi Károly, aki az Irsai Olivér és Tramini keresztezéséből állította elő, 1960-ban. Az 1980-as évek közepén bekövetkezett óriási fagykárok után nagyon gyorsan terjedt mind hegy-, domb- és síkvidéki szőlőtermelök körében. 1982-ben lett államilag elismert. Korán érő szölőfajta. Ennek ellenére a szüretre csak szeptember második felében szokott sor kerülni. A terméshozama 10-12 t/ha, ami átlagosnak mondható. A bogyó cukortartalma átlagosan $18 \mathrm{Mm}^{0}$, de nem ritka az ennél nagyobb mustfok. Mindehhez egy 8$10 \mathrm{~g} /$ l-es savtartalom társul, ami az érés folyamán nem lágyul. (HAJDU, 2003, LELKES, 2004).

Négy különbözö időpontban vett mintát vizsgáltunk, amelyek a következők: augusztus 3 és 29 , szeptember 20 és október 7-e voltak, mindkét vizsgált szőlöfajta esetében.

A szőlő gyümölcsének fö alkotói a szénhidrátok, melyek nagyban befolyásolják annak minőségét. $\mathrm{Az}$ egyes anyagok értékét analitikai vizsgálatokkal határozhatjuk meg. A meghatározási módszereket két nagy csoportra bonthatjuk, kvalitatív és kvantitatív, azaz minöségi, és mennyiségi meghatározásokra. A minták cukortartalmának vizsgálatára több módszert is alkalmaztunk, így kémiai és biológiai (enzimes) eljárással is meghatároztuk a cukrok értékét. A kémiai analitikai eljárásnál Schoorl-Regenbogen módszert használtunk az MSZ 20900/5-89-es szabvány alapján. A glükóz és fruktóz arány meghatározására használt biokémiai módszer az alábbi volt. Az eljárás során BOEHRINGER MANNHEIM / RBIOPHARM enzim kit-jét, valamint Hitatchi U-2900 spektrofotométert használtunk. A mérések során minden új kit alkalmazásánál vakpróbát végeztünk. A mustmintáknál megfelelö hígitást végeztünk, így elkerülve a kiugró abszorbancia értékeket. A hígítás mértékét egy elözetes refraktometriás vizsgálat alapján határoztuk meg. A minták koncentrációját az alábbi képlet kiszámítása után kaptuk:

$$
\mathrm{c}=\frac{\mathrm{V} \cdot \mathrm{MW}}{\varepsilon \cdot \mathrm{d} \cdot \mathrm{v} \cdot 1000} \cdot \Delta \mathrm{A}[\mathrm{g} / \mathrm{l}]
$$

Ahol:

$\mathrm{v}$ - minta térfogat $(\mathrm{ml})$

$\mathrm{V}$-végső térfogat ( $\mathrm{ml})$

MW - a vizsgált anyag moltömege $(\mathrm{g} / \mathrm{mol})$

$\mathrm{d}-$ fényút $\mathrm{cm}$

$\varepsilon-\mathrm{NADPH}$ extinkciós koefficiense

$$
340 \mathrm{~nm}-\mathrm{en}=6,3\left(\mathrm{l} \mathrm{mmol}^{-1} \mathrm{x} \mathrm{cm}^{-1}\right)
$$

Behelyettesítés után a következő egyenletek adódtak:

D-glükózra: 


$$
\begin{aligned}
& \mathrm{c}=\frac{3,020 \cdot 180,16}{\varepsilon \cdot 1,00 \cdot 0,100 \cdot 1000} \cdot \Delta \mathrm{A}_{\mathrm{D}-\text { dlakóz }}=\frac{5,441}{\varepsilon} \cdot \Delta \mathrm{A}_{\mathrm{D}-\text { glakózz }}[\mathrm{g} \mathrm{D}-\mathrm{glükó} \mathrm{z} / \mathrm{I} \text { mintaoldat }] \\
& \text { D-fruktózra: } \\
& \mathrm{c}=\frac{3,040 \cdot 180,16}{\varepsilon \cdot 1,00 \cdot 0,100 \cdot 1000} \cdot \Delta \mathrm{A}_{\mathrm{D}-\text { fruktioz }}=\frac{5,477}{\varepsilon} \cdot \Delta \mathrm{A}_{\mathrm{D}-\text { frukkóz }}[\mathrm{g} \mathrm{D}-\text { fruktóz } / 1 \text { mintaoldat }]
\end{aligned}
$$

Mivel minták relativ magas cukortartalommal rendelkeztek, ezért hígítani kellet, ezért a kapott eredményeket meg kellett szorozni egy $\mathrm{F}$ hígitási tényezővel is.

\section{EREDMÉNYEK ÉS KÖVETKEZTETÉSEK}

A méréseink jól visszaadják az irodalomban megfogalmazott cukormennyiség változásokat az érés különböző fázisaiban. A zsendülés kezdetével nő a cukortartalom, majd a túlérés kezdetével csökkenésnek indul. Elmondható, a maximális cukortartalmat a Cserszegi füszeres 9. hónap 20.-a, míg az Olaszrizling 9. hónap 30.-a körül éri el. Az időbeli eltolódás a fajták közti érés különbséget jól szemlélteti az 1 . ábra.

1. ábra: Cukortartalom változása az érés során

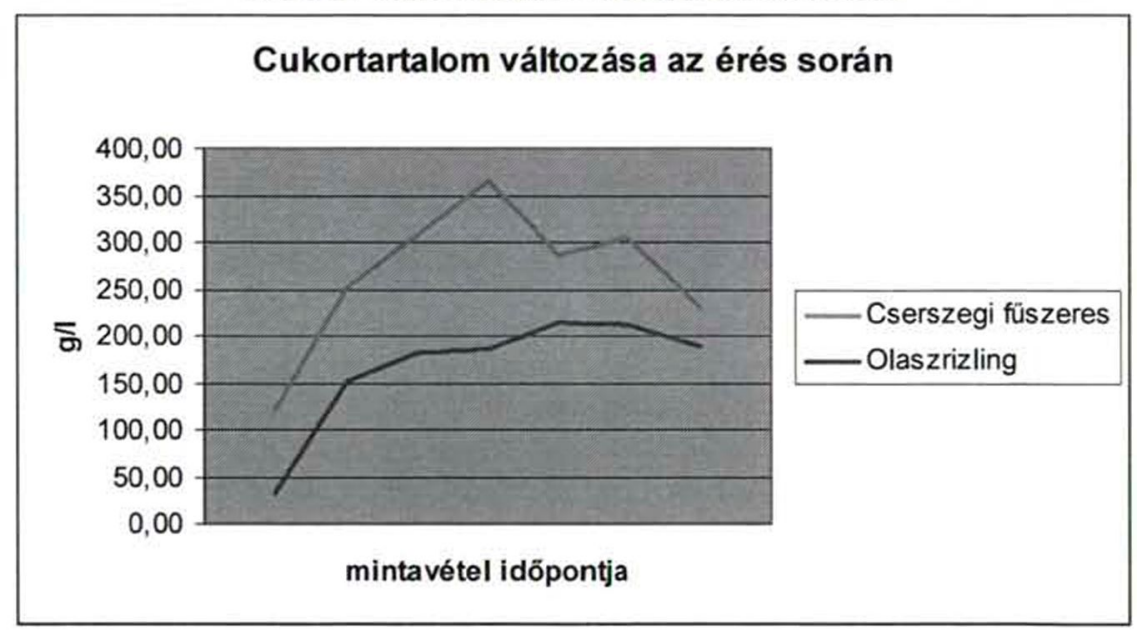

Mintavétel időpontja nincs jelezve az 1-es ábra alatt !/

Az optimális érési időpontot, ahogy arra korábban utaltunk meglehetősen nehéz meghatározni, mivel számtalan tényező befolyásolhatja, de akkor beszélhetünk érett termésröl a szölő esetében, amikor a bogyók cukortartalma a magas és bennük lévő glükóz és fruktóz mennyiségi aránya közel 1:1. A szakirodalom által leirt módon, az érés kezdetekor jóval magasabb arányban található glükóz a termésben, és majd csak az érés folyamán egyenlítődik ki ez az érték. A Cserszegi füszeres esetében jól megfigyelhető ez a változás. A cukortartalom növekedése közben a glükóz tartalom mérséklődik, majd a túlérett gyümölcsben az arány a fruktóz felé tolódik el. Az Olaszrizling esetében is szembetünő a változás, azonban a fruktózglükóz aránya az érés kezdetekor is 1:1.

Az Olaszrizling fajtánál jól láthatóan (2. ábra) ez az arány már az első vizsgálat időpontjában, augusztus 3-án beállt és később az idő előrehaladtával a fruktóz javára eltolódott. 
2. ábra: A Glükóz-fruktóz arány átlagértékei különböző mintavételi időpontonként

Olaszrizling esetében

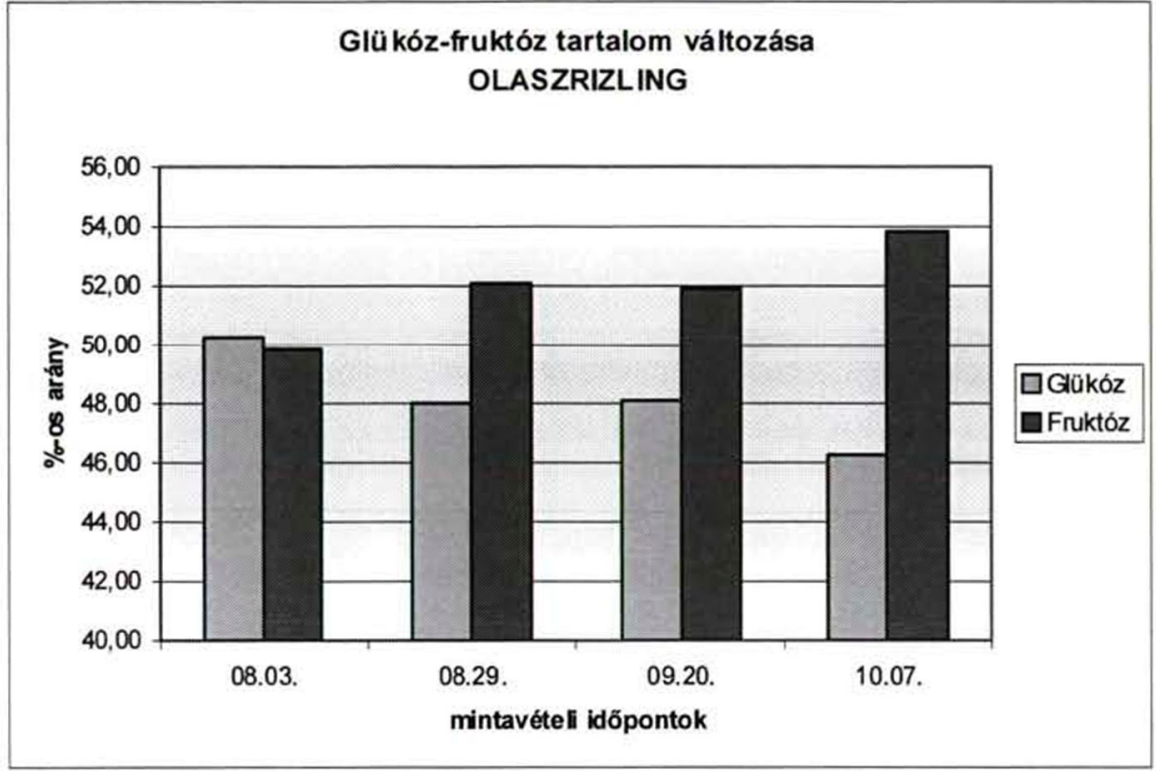

A Cserszegi füszeres szölöfajta esetében már a legkorábbi idejü mintavételkor is alacsonyabb kezdeti fruktóz arányt mértünk, amely az utolsó mintavétel idöpontjára - ha kismértékben-, de meghaladta az Olaszrizlingnél mért értéket. A 3. ábrán az is szembetünö, hogy a glükózfruktóz arány viszonylag gyorsan fordult át. Mivel egyetlen év mintáit vizsgáltuk elhamarkodott volna ebböl messzemenő következtetést levonni, de a tendencia figyelemre méltó és valószinűsíthető, hogy a fajta korai jellege, valamint a meleg, csapadékszegény időjárás egyaránt hatást gyakorolt.

3. ábra: A Glükóz-fruktóz arány átlagértékei különböző mintavételi idöpontonként Cserszegi füszeres szölöfajtánál

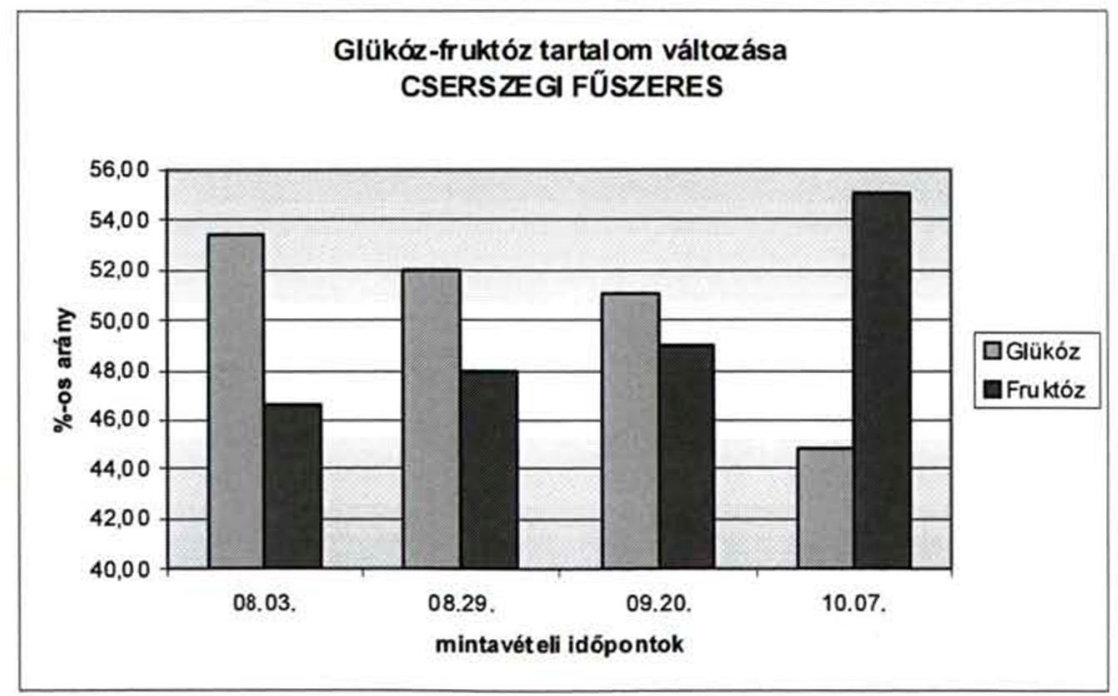


A leglényegesebb eredmény, a glükóz-fruktóz arány $(\mathrm{G} / \mathrm{F})$ alakulásánál mutatkozott, ahol a korainak számító Cserszegi füszeres fajta $\mathrm{G} / \mathrm{F}$ értéke lényegesen később tolódott el a fruktóz felé.

\section{KÖSZÖNETNYÍLVÁNÍTÁS}

A szerzök köszönetet mondanak a kutatás támogatásáért, amely a GOP-2009-1.1.1 számú kutatási-fejlesztési pályázat keretén belül történt.

Személyes köszönet illeti Bakos Tiborné és Kertai Zoltán tanszéki mérnököket a kísérleti minták elökészítéséért és feldolgozásáért.

\section{IRODALOMJEGYZÉK}

Bakonyi L.-Bényei F.-Fazekas I.-Hajdu E.-Korbuly J.-Lörincz A. - Marcinkó F. - Pernesz Gy. Romenza R. - Zanathy G. (2005): Borszölöfajták, csemegeszölöfajta-fajták és alanyok. Mezőgazda Kiadó, Budapest

Bényei F. - Lőrincza A. - Sz Nagy L. (1999): Szölötermesztés. Mezőgazda Kiadó, Budapest

Kádár Gy. (1982): Borászat. Mezőgazdasági Kiadó, Budapest

Eperjesi I. - Horváth Cs. - Sidlovits D. - Pásti Gy. (2010): Borászati technológia. Mezőgazda Kiadó, Budapest

Eperjesi I. - Kállay M. (1998): Borászat. Mezőgazda Kiadó, Budapest

Hajdu E. (2003): Magyar szölófajták. Mezõgazda Kiadó, Budapest

Kállai M. (2010): Borászati kémia. Mezőgazda Kiadó, Budapest

Lelkes L. (2004): Magyar borhagyományok, borivási szokások. Mezỏgazda Kiadó, Budapest

Márkus P. (2006): Borászati és üdítőital-ipari technológia I. FVM Képzési és Szaktanácsadási Intézet Zanatthy G. (1999): Szölötermesztés. Mezőgazda Kiadó, Budapest 